\title{
Activated Notch1 is a stronger astrocytic stimulus than leukemia inhibitory factor for rat neural stem cells
}

\author{
NIDIA S. RODRÍGUEZ-RIVERA, ANAYANSI MOLINA-HERNÁNDEZ, \\ ERIKA SÁNCHEZ-CRUZ, DIANA ESCALANTE-ALCALDE and IVÁN VELASCO* \\ Departamento de Neurociencias, Instituto de Fisiología Celular, Universidad Nacional Autónoma de México, México D.F., México
}

\begin{abstract}
Neural stem cells (NSC) self-renew and generate specialized cell types. There are reports indicating that Notch and Leukemia Inhibitory Factor (LIF) signaling are involved in cell determination of NSC, either preventing differentiation or promoting astrocytic fate. In this work, we aimed to compare the astrocytogenic effect of activated Notch with that induced by LIF. To this end, rat cerebral cortex neural progenitors/NSC were transduced with retroviral vectors in order to express green fluorescent protein (GFP), or a fusion protein of GFP with the active Notch1 intracellular domain (NICD). In parallel, other cultures were treated with increasing concentrations of LIF. We confirmed, in proliferating NSC, that LIF activated intracellular effectors by measuring STAT3 phosphorylation and Socs 3 transcription. In NICD-expressing cells, Hes5 mRNA was induced, an effect not present in GFP-transduced NSC. We quantified the proportion of cells expressing Nestin in the presence of Fibroblast Growth Factor-2 (FGF-2) with LIF or NICD treatments. LIF significantly increased the proportion of cells co-expresssing Nestin and Glial Fibrillary Acidic Protein (GFAP), an effect absent in cells with activated Notch. After FGF2 withdrawal to promote differentiation, Nestin was markedly down-regulated, and neuronal and glial markers appeared in control cultures. LIF treatment caused a significant increase in the proportion of GFAP-positive cells, but cells expressing NICD showed a significantly higher percentage of astrocytes than control and LIF-treated cultures. These experiments show that cells stimulated with NICD differentiate more readily to astrocytes than LIF-treated NSC.
\end{abstract}

KEY WORDS: neural precursor, cerebral cortex, Sox2, CNTF, GFAP

\section{Introduction}

Notch is a highly conserved protein family that directs signaling mechanisms involved in proliferation and differentiation of a large number of cell types (Artavanis-Tsakonas et al., 1999). Notch activation is triggered by interaction with their ligands, Delta or Jagged. This union cause proteolysis of Notch, and its intracellular fragment (NICD) is released to interact in the nucleus with CBF1, causing transcriptional activation of Hes genes (Corbin et al., 2008). In mammalian Central Nervous System (CNS), Notch1, 2 and 3 are present in the developing neuroectoderm and their expression persists until adulthood (Yoon and Gaiano, 2005). Gain- and loss-of-function experiments have demonstrated that activated Notch1 plays an important role in preventing neural precursor differentiation in developing CNS, including the cerebral cortex (Gaiano et al., 2000; Lutolf et al., 2002; Chojnacki et al., 2003; Yoon et al., 2004; Mizutani and Saito, 2005). The periventricular cortical zone contains dividing multipotent neural stem cells (NSC) that self-renew and differentiate in a first phase to neurons, later to astrocytes and finally to oligodendrocytes. Activated NICD is present only in the ventricular zone (Tokunaga et al., 2004) and Notch activity has also been shown to promote radial glia identity (Gaiano et al., 2000). Radial glia cells express Glial Fibrillary Acidic Protein (GFAP) and have been identified as NSC in the cerebral cortex (Noctor et al., 2001). Notch activation has been shown to promote survival of neural precursors (Oishi

\footnotetext{
Abbreviations used in this paper: CNS, central nervous system; CNTF, cilliary neurotrophic factor; FGF-2, fibroblast growth factor-2; GAPDH, glyceraldehyde 3-phosphate dehydrogenase; GFAP, glial fibrillary acidic protein; GFP, green fluorescent protein; JAK, Janus kinase; LIF, leukemia inhibitory factor; LIFR $\beta$, LIF receptor $\beta$; NSC, neural stem cells; NICD, Notch1 intracellular domain; Socs, suppressor of cytokine signaling; STAT, signal transducer and activator of transcription.
}

*Address correspondence to: Dr. Iván Velasco. Departamento de Neurociencias, Instituto de Fisiología Celular, Universidad Nacional Autónoma de México. AP 70-253, México D.F. 04510, México. Fax: 5255-5622-5607. e-mail: ivelasco@ifc.unam.mx 
et al., 2004; Androutsellis-Theotokis et al., 2006). Notch stimulation can also prevent neurogenesis of pluripotent stem cells (Nye et al., 1994) and oligodendrocyte differentiation of glial precursors (Wang et al., 1998). Activated Notch promotes Schwann cell differentiation from neural crest stem cells (Morrison et al., 2000), and astrocytic differentiation in NSC from developing (Grandbarbe et al., 2003) and adult CNS (Tanigaki et al., 2001).

On the other hand, Leukemia Inhibitory Factor (LIF) and Cilliary Neurotrophic Factor (CNTF) are powerful inducers of NSC differentiation to astrocytes. These cytokines activate heteromeric receptors composed by LIF receptor $\beta$ and GP130, which signal through activation of Janus kinase (JAK)/Signal Transducer and Activator of Transcription (STAT) pathway to promote glial commitment (Bonni et al., 1997; Rajan and McKay, 1998; Molne etal., 2000). STAT3 is activated by phosphorylation after LIF receptor stimulation. This pathway also causes the transcriptional activa-

A

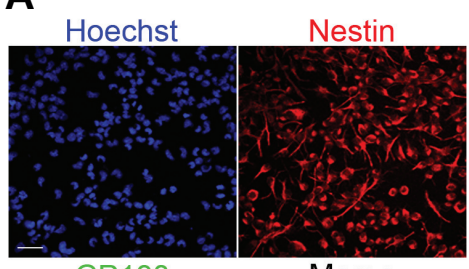

B
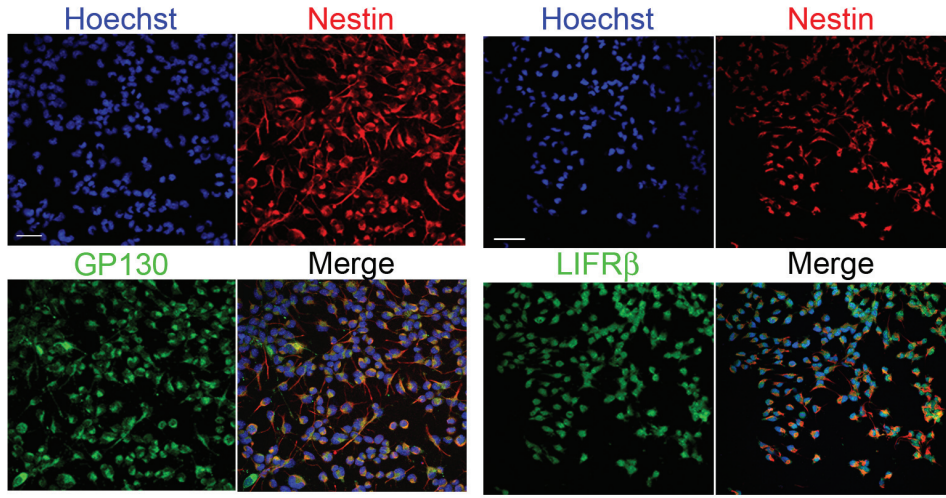
LIFR $\beta$ Merge

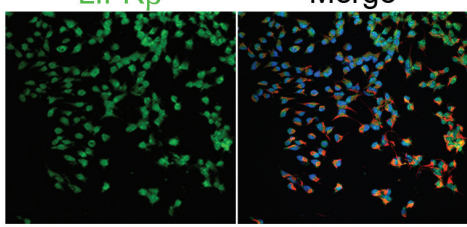

C CONTROL

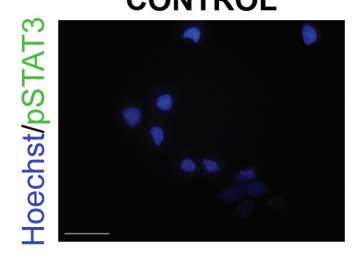
LIF $10 \mathrm{ng} / \mathrm{ml}$
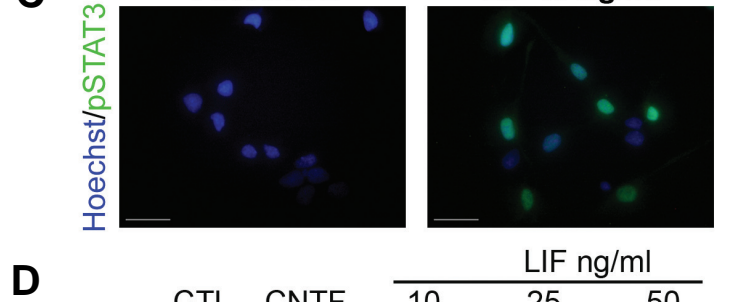

LIF $\mathrm{ng} / \mathrm{ml}$

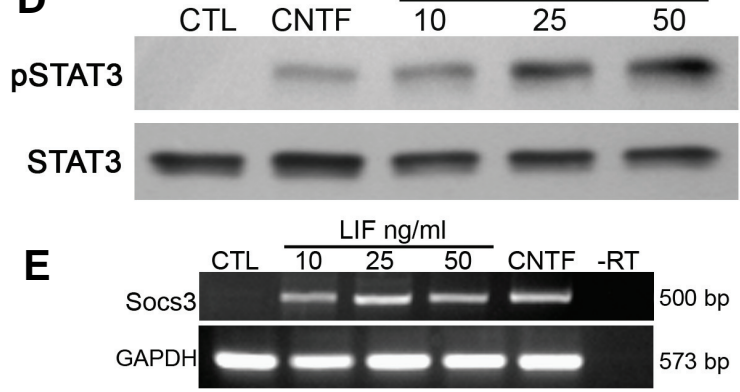

Fig. 1. Cortical NSC respond to LIF and CNTF stimulation. Proliferating neural progenitors/NSC expressed Nestin $(\mathbf{A}, \mathbf{B})$ together with GP130 (A) or LIFR $\beta$ (B). In control cultures, no signal for phospho (p)STAT3 was detected (C). After addition of LIF, NSC show nuclear pSTAT3. Accordingly, in immunoblot assays, control (CTL) cells have non-phosphorylated STAT3, and $10 \mathrm{ng} / \mathrm{m} / \mathrm{CNTF}$ or the indicated LIF concentrations induced phosphorylation of STAT3 (D). The transcriptional activation of Socs3 is only found in cells stimulated with LIF or CNTF (E). Images are representative of 3 independent experiments performed in duplicate. Scale bars represent $20 \mu \mathrm{m}$ for $A$ and 50 $\mu \mathrm{m}$ for $B$. -RT, RNA without reverse transcriptase. tion of suppressor of cytokine signaling (Socs) 3. Socs3 association to GP130 constitutes a negative feedback loop that decrease GP130-mediated transduction in NSC (Emery et al., 2006). Although the most consistent effect of LIF stimulation of NSC is gliogenesis, there is evidence that LIF, in the presence of Epidermal Growth Factor and Fibroblast Growth Factor (FGF)-2, can increase clonogenic potential of NSC (Pitman et al., 2004). Thus, Notch and LIF share effects on NSC, inhibiting cell differentiation, or promoting glial phenotypes. In this work we analyzed the effect of expressing NICD in rat cortical neural progenitors/NSC in vitro at a time when neurogenesis is normally favored, in order to compare it with the action of LIF, a well-described glial differentiation inductor. We found that although LIF induced the expression of the astrocytic marker GFAP during proliferation, cells that have activated Notch during differentiation produced a significantly higher proportion of GFAP-positive cells.

\section{Results}

\section{NSC express receptors for LIF/CNTF and respond to appli- cation of such cytokines}

In order to establish if our cortical cultures respond to LIF and CNTF stimulation, we performed immunodetection of Nestin, a filamentous protein characteristic of neural progenitors including NSC, together with GP130 and LIF receptor $\beta$ (LIFR $\beta$ ) in cells exposed to $10 \mathrm{ng} / \mathrm{ml}$ of the mitogenic agent FGF-2. Under these conditions, Nestin was expressed in 94.0 $\pm 2.3 \%$ of cells, whereas GP130 was present in $94.7 \pm 5.4$ (Fig. $1 \mathrm{~A}$ ) and LIFRß (Fig. 1B) was detected in $92.2 \pm 5.3 \%$ of cultured cells. Although $10 \mathrm{ng} / \mathrm{ml}$ of LIF is enough to preserve mouse embryonic stem cells undifferentiated (Díaz et al., 2007), we performed experiments with higher concentrations of LIF, to reach saturating concentrations in terms of GP130 / LIFR $\beta$ activation. In some instances, the effect of LIF was compared to that of $10 \mathrm{ng} / \mathrm{ml} \mathrm{CNTF}$, a cytokine reported to increase astrocytogenesis from NSC at this concentration (Johe et al., 1996). We determined STAT3 phosphorylation at tyrosine 705 (pSTAT3) after a stimulation of 30 min with CNTF, or increasing concentrations of LIF. In control conditions, we did not detect any pSTAT3 signal by immunocytochemistry, while LIF stimulation clearly promoted the appearance of nuclear PSTAT3 (Fig. 1C); we did not find differences in the proportion of cells with pSTAT3 when applying CNTF $(42.8 \pm 6.5 \%)$ or LIF at 10 $\mathrm{ng} / \mathrm{ml}(38.2 \pm 6.5 \%), 25 \mathrm{ng} / \mathrm{ml}(38.8 \pm 6.0 \%)$ and $50 \mathrm{ng} / \mathrm{ml}(39.3$ \pm 6.9 ). Using immunoblot, we observed a similar induction in STAT3 phosphorylation with $10 \mathrm{ng} / \mathrm{ml} \mathrm{CNTF} \mathrm{and} 10 \mathrm{ng} / \mathrm{ml}$ LIF; higher LIF concentrations increased the amount of PSTAT3 (Fig. 1D). When we analyzed the induction of Socs3transcription after stimulation of cells with cytokines for $1 \mathrm{~h}$, CNTF and LIF at all tested concentrations caused similar increases in Socs 3 mRNA (Fig. 1E).

\section{NICD is found in the nucleus and activates Hes5}

In order to stimulate Notch signaling in NSC, we employed retrovirus that express green fluorescent protein (GFP, control) or a fusion protein of GFP with NICD (GFP-NICD). As reported previously (Yoon et al., 2004), GFP expression pattern was different in control- and NICD-transduced cells: GFP is observed thought the entire cell (Fig. 2A) and the fusion protein 


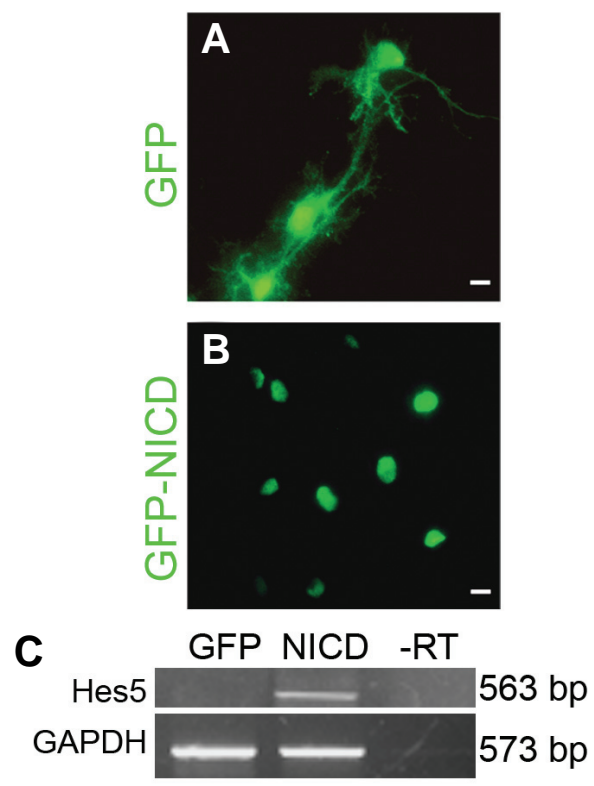

Fig. 2. Activation of Notch pathway in NSC transduced with retroviral vectors. Proliferating neural precursors were transduced with retrovirus in the presence of FGF-2. (A) Cells incubated with control viruses express GFP in both somata and processes. (B) Neural precursors transduced with GFP-NICD present green fluorescence only in the nucleus. (C) Hes5 mRNA is not detected in GFP-expressing cultures, but is present in NICD cells. Images are representative of $3-8$ independent experiments performed in duplicate. Scale bars for $A$ and $B$ represent $10 \mu \mathrm{m}$. - RT, RNA without reverse transcriptase.

GFP-NICD was restricted to the nucleus (Fig. 2B). We also examined by RT-PCR the mRNA levels of Hes5, a Notch-activated gene, and observed that Hes5 was undetectable in controls, and NICD promoted its transcription, indicating Notch activity in such cells (Fig. 2C).

\section{Under proliferative conditions, LIF and CNTF promote GFAP expression}

We evaluated expression of the neural progenitors/NSC marker Nestin, alone or in combination with the differentiation markers $\beta$ Tubulin III and GFAP, in cells cultured with FGF-2. As already mentioned, in control conditions, the proportion of Nestin-positive cells was above $94 \%$. LIF at 10 and $50 \mathrm{ng} / \mathrm{ml}$, and $10 \mathrm{ng} / \mathrm{ml}$ CNTF (Fig. 3 A,D) induced the appearance of cells that co-express Nestin and GFAP in numbers ranging from 20 to $40 \%$. These GFAPpositive cells induced by LIF treatment also express Sox2, a transcription factor expressed by neural progenitors including NSC: from the total GFAP-expressing cells, $90.11 \pm 3.1 \%$ (CNTF), $83.1 \pm 6.4 \%$ (10 ng/ml LIF), $93.8 \pm 2.0 \%$ ( $25 \mathrm{ng} / \mathrm{ml} \mathrm{LIF)} \mathrm{and} 89.4 \pm 3.7 \%$ (50 ng/ mI LIF) were also Sox2-positive (Fig. 3B). In addition, CNTF significantly increased to $8 \%$ the proportion of cells expressing GFAP without Nestin (Fig. 3D). In retroviral controls, Nestin expression was above $90 \%$ in the GFP-positive population, and this proportion was not modified in NICD-expressing cells (Fig. 3 C,D). NICD, similar to CNTF, also increased GFAP-positive cells, but did not increase the number of cells co-expressing Nestin and GFAP (Fig. 3D). Although NICD cells express Nestin in a high proportion, it was possible to appreciate the differences in the morphology when compared with controls: cells expressing NICD were larger, their nuclei were elongated and they presented long processes resembling an astrocytelike shape (Fig. 3C).

We also analyzed if these treatments could induce premature neuronal differentiation in cells treated with FGF-2. We found that in all tested conditions, the proportion of $\beta$-Tubulin III (detected with TUJ1 antibody), alone or in combination with Nestin, was always below $1.5 \%$ (Fig. 3D). Regarding transduction efficiency, in these experiments we confirmed that we had a similar proportion of GFPexpressing cells in GFP and NICD conditions (GFP: $7.2 \pm 1.9 \%$; GFP-NICD: $6.1 \pm 1.7 \%$ ). We also observed that in both cases, GFP+ cells formed colonies, which suggest that transduced cells were clonally derived.

\section{NICD-expressing cells differentiate to astrocytes more effi- ciently than LIF-treated NSC}

After 4-6 days of FGF-2 withdrawal, differentiation of neural progenitors/NSC was analyzed. We evaluated the presence of $\beta$ Tubulin III and GFAP as markers of neurons and astrocytes, respectively. Since we wanted to test the astrocytic-inducing activity of LIF and Notch, we decided to use cells at passage 1 because they are more neurogenic than cells at later passages (Chang et al., 2004; Molina-Hernández and Velasco, 2008), allowing us to clearly observe astrocyte differentiation. We found that under control conditions neural progenitors/NSC differentiate more readily to neurons than to astrocytes (Fig. 4 A,E). In contrast, LIF treatment at 10 (Fig. $4 \mathrm{~B}, \mathrm{E})$ or $50 \mathrm{ng} / \mathrm{ml}$ (Fig. $4 \mathrm{E}$ ) caused significant increases in the number of GFAP-positive cells (up to $75 \%$ ), and also a significant decrease in neurogenesis. CNTF was only effective in decreasing the proportion of neurons, although it augmented GFAP percentage non-significantly from $39 \%$ (control) to $56 \%$ (Fig. 4E). For cells transduced with retrovirus, we only quantified the GFP-expressing population (Fig. 4 C-E). In control GFP-positive cells, there was a similar proportion of neurons and astrocytes after differentiation (Fig. $4 \mathrm{E})$, whereas cells that expressed GFP-NICD presented only GFAPpositive cells, with exception of 7 cells out of 1778 assessed ( $0.4 \%)$ in 8 independent experiments. Both LIF-treated and NICD-expressing cells produced significantly more astrocytes than their respective controls. However, NICD-expressing cells had a significantly higher proportion of GFAP-positive cells than LIF treatments (Fig. 4E). To assess if Notch or JAK-STAT signaling could preserve cells undifferentiated in the absence of FGF-2, we evaluated Nestin expression in this differentiation phase, when this marker is normally down-regulated. None of the experimental treatments used here caused cells to continue expressing Nestin, with a few exceptions where a dim Nestin signal was detected in GFAP- or TUJ1-expressing cells (Fig. 4E).

\section{Discussion}

In the experiments presented here, we show that LIF/CNTF treatment of proliferating neural progenitors/NSC induced coexpression of the undifferentiated neural markers Nestin and Sox2, with GFAP. Notch activation did not increase significantly the percentage of cells expressing GFAP at this stage. After FGF2 withdrawal, both LIF and Notch caused significant increases in the proportion of astrocytes; this side-by-side comparison showed that Notch activation is a stronger astrocytic-promoting signal than LIF, since practically all NICD-expressing cells differentiated 
to GFAP-positive cells. The role of NICD in proliferating NSC is to prevent neuronal differentiation. It is possible that, in the absence of FGF-2, NICD also prevents neurogenesis but not gliogenesis, allowing cells to proceed to astrocyte differentiation.

LIF and CNTF stimulate receptors that include GP130 and LIFR $\beta$. This activation causes tyrosine phosphorylation of STAT3, which translocates to the nucleus. In our study, we show that a high proportion (> 90\%) of cultured cells express GP130 and LIFR $\beta$ (Fig. 1 A,B). When we evaluated the presence of pSTAT3 30 min after LIF or CNTF addition, we found a smaller proportion

A

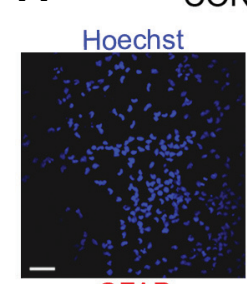

GFAP
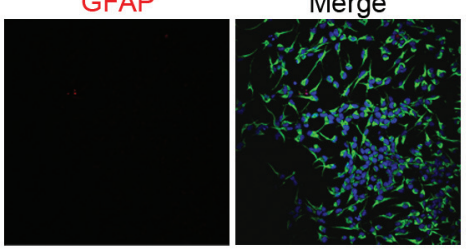

B

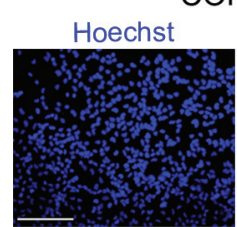

GFAP

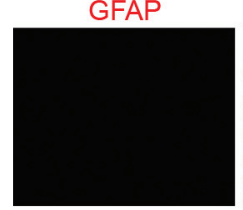

C

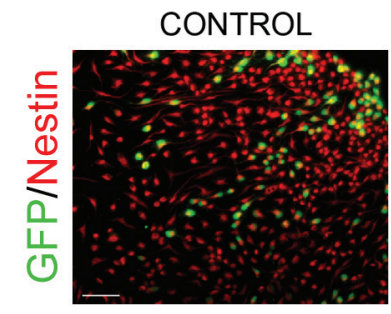

D

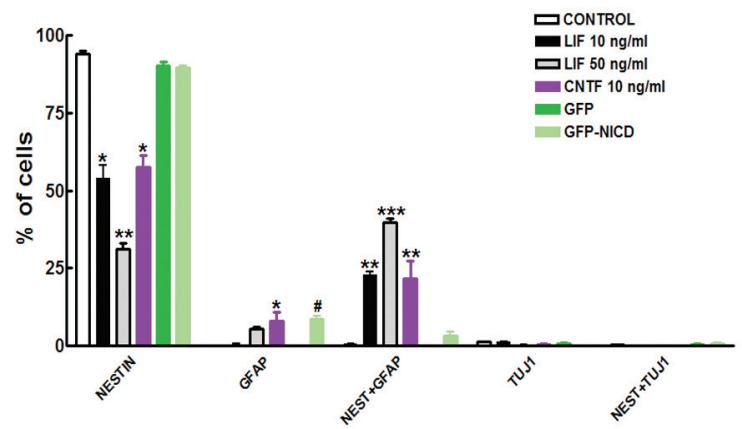

$(<43 \%$ ) of positive cells (Fig. 1C), indicating that not all neural progenitors/NSC are equally responsive to LIF/CNTF application. As previously reported (Emery et al., 2006), we observed nuclear pSTAT3 and Socs3transcriptional activation after LIF and CNTF stimulation of NSC. We did not find significant differences in the proportion of cells expressing PSTAT3 by immunocytochemistry nor in Socs3induction by RT-PCR. In Western blot, we found that high LIF concentrations were more effective than CNTF and 10 $\mathrm{ng} / \mathrm{ml}$ LIF in phosphorylating STAT3. This effect seems to be preserved when we analyzed the percentage of cells co-expressing GFAP and Nestin. However, 10 or $50 \mathrm{ng} / \mathrm{ml}$ LIF were equally effective in inducing astrocyte differentiation in the absence of FGF-2 (Fig. 4E). Co-expression of GFAP in Nestinpositive cells after LIF/CNTF treatment is not indicative of glial commitment, as demonstrated by the high proportion of GFAP cells that express Sox2 (Fig. 3B). This Nestin/GFAP coexpression is probably mediated by transcriptional activation of the Gfappromoter by pSTAT3, and did not involve dramatic change in cell shape. In contrast, NICD-expressing cells present clear changes in cell size and shape, reminiscent of astrocyte morphology, even when they do not express GFAP and remain Nestin- (Fig. 3C) and Sox2-positive (data not shown).

NSC in culture recapitulate to some extent the differentiation compromise described in vivo(Qian etal., 2000; Sauvageot and Stiles, 2002; Chang et al., 2004): early NSC are more prone to produce neurons, whereas older NSC produce glia (astrocytes first and oligodendrocytes later). In our control cultures, we found that cells differentiate preferentially to neurons. As described earlier, LIF treatment (Molne et al., 2000) and Notch activation (Morrison et al., 2000; Chambers et al., 2001; Grandbarbe et al., 2003) switched this differentiation potential to an astrocytic one. Exposure of NSC to CNTF induced Notch1 expression (Chojnacki et al., 2003) without activating expression of Notch-responsive genes such as Hes (Chojnacki et al., 2003; Androutsellis-Theotokis et al., 2006). CNTF/LIF effects are mediated through tyrosine 705 phosphorylation in STAT3. However, phosphorylation of serine residue 727 of STAT3 has been reported after Jagged1 addition to

Fig. 3. LIF and CNTF treatment of proliferating NSC causes Nestin/GFAP co-expression. Cortical neural precursors were incu-

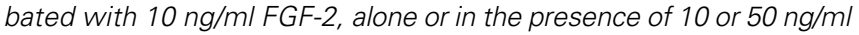
of LIF, or $10 \mathrm{ng} / \mathrm{ml}$ CNTF. Also, GFP and GFP-NICD transduced cells were incubated with FGF-2. Nestin and Sox2 (neural progenitor/NSC markers), GFAP (astrocytic marker) and $\beta$-Tubulin III (neuronal protein recognized by TUJ1 antibody) expression was evaluated in these conditions. Control cells showed very rarely differentiation markers (A,D). Treatments with $10 \mathrm{ng} / \mathrm{ml} \mathrm{LIF}$ (A), $50 \mathrm{ng} / \mathrm{ml}$ LIF or $10 \mathrm{ng} / \mathrm{ml}$ CNTF (D) caused significant increases in GFAP expression without Nestin (NEST) down-regulation. GFAP-positive cells after LIF treatment express Sox2 (B). GFP-expressing cells were also Nestinpositive in a high proportion (C,D). Expression of GFP-NICD by neural precursors (C) did not induce GFAP expression in Nestin positive cells. Several Nestin+ NICD-expressing cells showed flat and large cell somata, resembling astrocyte-like morphologies (C). Images are representative of 3 independent experiments performed in duplicate. The plot shows means \pm standard error of 4-8 independent experiments. ${ }^{*} P<0.05,{ }^{*} P<0.01$ and ${ }^{*}{ }^{*} P<0.001$ versus control condition. \# $P$ $<0.05$ versus GFP cells. Scale bars represent $25 \mu \mathrm{m}$ in $A, 100 \mu \mathrm{m}$ in $B$ and $50 \mu \mathrm{m}$ in $\mathrm{C}$. 

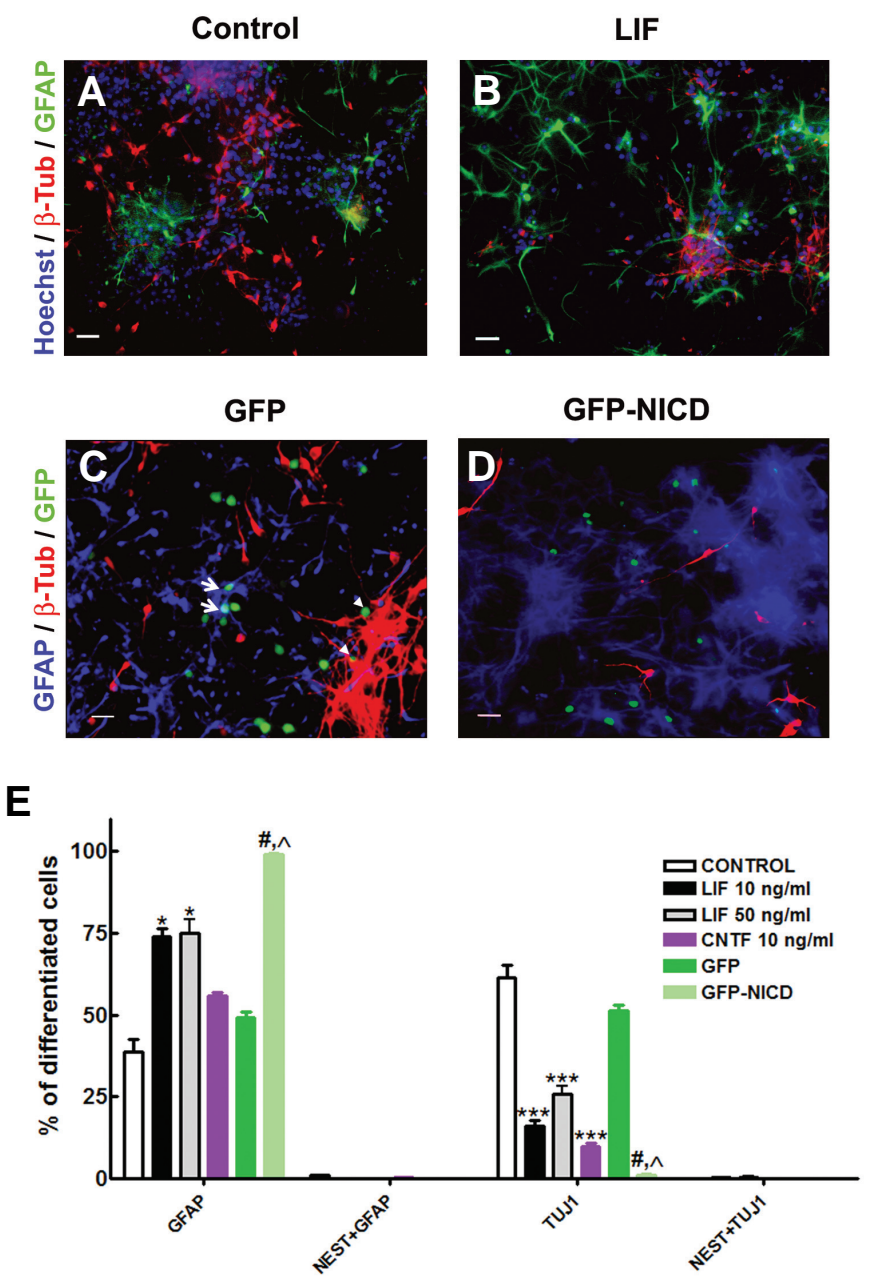

Fig. 4. Activated Notch1 is a stronger astrocyte inductor than LIF for cortical NSC. Cells in the conditions described in Fig. 3 were allowed to differentiate for 4-6 days after FGF-2 withdrawal. Neural progenitor/NSC (Nestin), neuronal ( $\beta$-Tubulin III, detected by TUJ1 antibody) and astrocytic markers (GFAP) were quantified. In retroviral-treated cultures, only the GFP-expressing population was analyzed. In control cultures, neural progenitors/NSC produced more neurons than astrocytes $(\mathbf{A}, \mathbf{E})$. Treatment with 10 (B) or $50 \mathrm{ng} / \mathrm{ml}$ LIF (E) significantly switched these proportions to astrocyte differentiation. In control GFP cells, neuronal and glial differentiation did not differ from control conditions (C,E). In C, GFP cells that express GFAP are labeled with arrows, and GFP $+/ \beta$-Tubulin III+ cells are indicated by arrowheads. In the case of GFP-NICD cells, practically all cells express GFAP (D,E). This latter condition was significantly different from both GFP/control and LIF treatments. Nestin (NEST)positive cells are very rarely observed in these conditions (E). Data were obtained from 4-8 independent experiments performed in duplicate. The graph shows means \pm standard error. ${ }^{*} P<0.05$ and ${ }^{* * *} P<0.001$ versus control condition. \# $P<0.05$ versus GFP cells. $\wedge P<0.05$ compared to LIFtreated cells. Scale bars, $25 \mu \mathrm{m}$.

NSC. Furthermore, Jagged1 stimulation of Hes3 expression in mouse neural precursors is reverted by CNTF exposure (Androutsellis-Theotokis et al., 2006). Also, it has been reported that an active form of Notch activates STAT-dependent promoters, and that this activation is facilitated by Hes 1 and Hes5. Dominant negative forms of STAT3 repressed such Hes-mediated transcriptional activation (Kamakura et al., 2004). These results start revealing the complex scenario in which NSC might be immerse, and suggest potential crosstalk between pathways activated by LIF and Notch. Cultured neural progenitors/NSC have been valuable to molecularly dissect important pathways that might be important in brain development.

Recently, similar to what is observed after GFP-NICD retroviral injection in developing CNS, activated forms of FGF receptors have been show to promote NSC identity and self-renewal in early precursors (Yoon et al., 2004). We have used the same retroviral vectors to express the active form of Notch 1 in cortical cells. The results reported here might seem conflicting with the fact that this group found that neural precursors transduced in vivo with GFPNICD, and isolated later by fluorescence activated cell sorting, were enriched in neurosphere-forming capacity and later were able to differentiate to neurons, astrocytes and oligodendrocytes. However, neurons and oligodendrocytes were present in cells that lost GFP-NICD expression. In the present set of experiments, we analyzed only cells that kept the Notch pathway active. In differentiated GFP-NICD expressing cells, GFAP expression was clear in over $99 \%$ of cells, and we did not detect Nestin in such GFAP-positive cells (Fig. 4E). There is a possibility for retroviral silencing in our experiments, but this putative population was not analyzed, since only GFP-expressing cells were considered. It is also worth to mention that the retroviral approach used in this study might select for rapidly dividing cells, while slow-dividing and quiescent cells are not infected, and thus these latter populations were not analyzed here. After differentiation, GFP-transduced cells show non-significant deviations from non-transduced controls in neuronal and astroglial differentiation, which might reflect subtle differences between these cell populations. In conclusion, our results show that neural progenitors/NSC respond to both LIF and NICD by differentiating to astrocytes. However, in the population that continues to express GFP-NICD glial differentiation is almost $100 \%$ efficient.

\section{Materials and Methods}

\section{Retroviral vectors}

We produced non-replicative retroviruses using the Pantropic Retroviral Expression System (Clontech), by transient co-transfection of GP2-293 packaging cells with plasmids coding the envelope protein VSV-G and the DNA of choice, as described earlier (Gaiano et al., 1999; Yoon et al., 2004). Virus containing the coding sequence for GFP alone (GIA plas$\mathrm{mid}$ ), and retrovirus that has GFP fused in frame to amino acids 1761 to 2531 from the intracellular Notch1 domain (GFP-NICD, GNIA vector) were made. These constructs were reported to be expressed in NSC in vivo, and the fusion protein GFP-NICD can activate downstream Notch targets (Gaiano et al., 1999; Yoon et al., 2004).

To verify that retroviruses were assembled correctly and were infective, we made control-assembling (G-Luc) virus by transfecting VSV-G plasmid into a packaging cell line stably transfected with the luciferase gene (GP2-293-Luc), provided with the pantropic kit. Supernatants of VSV-G transfected GP2-293-Luc cells were pooled and concentrated by ultracentrifugation $\left(2 \mathrm{~h}\right.$ at $82000 \times g$ at $\left.4^{\circ} \mathrm{C}\right)$. Ten microliters of G-Luc virus were added to $60-70 \%$ confluent $\mathrm{NIH} 3 \mathrm{~T} 310-\mathrm{cm}$ dishes, incubated at $37^{\circ} \mathrm{C}$ with $5 \%$ of $\mathrm{CO}_{2}$ for 2 days and then protein was extracted with lysis buffer ( $\mathrm{NaCl} 150 \mathrm{mM}$, Tris-HCl $20 \mathrm{mM}$, DTT $1 \mathrm{mM}$, Triton X-100 1\%, and $1 \mathrm{X}$ Roche protease inhibitors, $\mathrm{pH}$ 7.2). Untransduced NIH $3 \mathrm{~T} 3$ cells were used as negative controls. We performed luciferase assays at room temperature with $200 \mu \mathrm{l}$ of each sample, mixing them with $200 \mu$ l of assay buffer (Tricine $30 \mathrm{mM}$, DTT $10 \mathrm{mM}$, ATP $3 \mathrm{mM}, \mathrm{MgSO}_{4} 15 \mathrm{mM}, \mathrm{pH} 7.8$ ) 
and $200 \mu \mathrm{l}$ of D-Luciferin (Sigma) $1 \mathrm{mM}, \mathrm{pH} 6.5$ just before being placed on a luminometer. A solution of assay buffer with $\mathrm{D}$-Luciferin was used as blank. Luciferase activity was corrected by protein concentration determined by the Bradford assay. Bioluminescence was calculated as relative light units $(R L U) / \mu g$ of protein. Under these conditions, we confirmed that infective retrovirus were being produced, since untransduced fibroblasts had $0.06 \mathrm{RLU} / \mu \mathrm{g}$ of protein and G-Luc virus presented an activity of 48.29 $\mathrm{RLU} / \mu \mathrm{g}$ of protein.

After confirming viral production and infectivity, GFP and GFP-NICD virus were produced, concentrated and titrated using the plaque method, where serial dilutions of viral suspension were incubated with NIH 3T3 fibroblast to determine the number of GFP colonies present in each dilution calculating the number of colony forming units (c.f.u.) per $\mathrm{ml}$. Titers for different viral lots were between $3.5 \times 10^{4}-4.4 \times 10^{5}$ c.f.u. $/ \mathrm{ml}$. In fibroblast cultures exposed to control retrovirus, GFP could be observed throughout the cell, whereas in GFP-NICD cells, GFP expression was restricted to the nucleus.

\section{NSC primary cultures and retroviral transduction}

Neural progenitors/NSC were obtained by dissecting the brain cortical region from embryonic day 14 Wistar rat embryos using published protocols (Johe et al., 1996; Molina-Hernández and Velasco, 2008). All embryos and cortices were maintained on ice-cold Krebs solution. Dissected cortical tissue was centrifuged 5 minutes at $200 \times g$. The supernatant was discarded and the pellet was re-suspended in $1 \mathrm{ml}$ of $\mathrm{N} 2$ medium (DMEM/F12 1:1, supplemented with $25 \mu \mathrm{g} / \mathrm{L}$ of human insulin, $30 \mathrm{nM}$ sodium selenite, $100 \mu \mathrm{M}$ putrescine, $20 \mathrm{nM}$ progesterone and $100 \mathrm{mg} / \mathrm{l}$ apotransferrin) to mechanically dissociate it using a P1000 micropipette tip. The single-cell suspension was recovered and pellet was re-suspended again in $1 \mathrm{ml}$ of $\mathrm{N} 2$ medium to repeat pipette tip passages. Undissociated tissue was let to settle and discarded. Single cells were centrifuged at $200 \times g$ for $5 \mathrm{~min}$ at $4^{\circ} \mathrm{C}$. Cells were counted and seeded at $1-1.4 \times 10^{6}$ in $10-\mathrm{cm}$ diameter culture dishes treated with $15 \mu \mathrm{g} / \mathrm{ml}$ poliL-ornithine (PLO), and $1 \mu \mathrm{g} / \mathrm{ml}$ Fibronectin in N2 with $10 \mathrm{ng} / \mathrm{ml}$ of FGF-2 to promote proliferation, and incubated at $37^{\circ} \mathrm{C}$ with $5 \%$ of $\mathrm{CO}_{2}$. FGF-2 was added daily and N2 medium was changed every other day.

At a confluence of around $80 \%$, neural progenitors/NSC were passed to glass coverslips (Assistent, Germany) also treated with PLO/fibronectin in 24-well plates at a density of $1 \times 10^{4}$ cells per well. When cultures were $50 \%$ confluent, NSC were transduced with the viral vectors. We decided to work with low titers in order to be able to quantify transduction efficiency accurately, and to better evaluate differentiation of transduced cells. Viruses were left in contact with NSC during 2 days. After that time, media was changed for fresh N2 with FGF-2 and cells were left in these proliferative conditions during 4 more days. After this time, half of the coverslips in each condition were fixed with $4 \%$ paraformaldehyde in phosphate-buffered saline (PBS) for $20 \mathrm{~min}$ and saved for posterior analysis. Media was changed for the rest of the cultures to N2 with $200 \mu \mathrm{M}$ ascorbic acid to promote differentiation. This condition was sustained during 4-6 additional days, changing medium every other day. After differentiation, cells were fixed for 20 minutes with cold $4 \%$ paraformaldehyde/PBS. Additionally, we treated cells with $10 \mathrm{ng} / \mathrm{ml}$ (equivalent to 1000 $\mathrm{U} / \mathrm{ml}$ ), $25 \mathrm{ng} / \mathrm{ml}$ or $50 \mathrm{ng} / \mathrm{ml}$ of LIF daily, or with $10 \mathrm{ng} / \mathrm{ml} \mathrm{CNTF}$, and included a control condition without any virus nor LIF/CNTF. These later conditions were fixed at the same time points than the viral transductions.

\section{Electrophoresis and Western blot}

We performed immunoblots as described (Diaz et al., 2007; MolinaHernández and Velasco, 2008) using the Phospho-STAT3 kit from Cell Signaling following the recommendations provided by the manufacturer. Briefly, neural progenitors/NSC were grown to subconfluency and stimulated with CNTF or LIF for $30 \mathrm{~min}$. Cells were homogenized in lysis buffer supplemented with protease and phosphatase inhibitors (Roche, Germany). Proteins were obtained by centrifugation at $15,000 \mathrm{rpm}$ at $4^{\circ} \mathrm{C}$ for $15 \mathrm{~min}$, and supernatant was quantified by a modified Bradford assay
(BioRad, Germany). Proteins $(40 \mu \mathrm{g})$ were resolved on $8 \%$ SDS-PAGE and transferred to nitrocellulose membranes (Amersham Bioscience, USA) which were blocked with $5 \%$ non-fat dry milk and incubated overnight with primary antibodies. Pre-stained markers (Invitrogen) were included for size determination. Membranes were washed and incubated with corresponding horseradish peroxidase-coupled secondary antibodies (Santa Cruz Biotechnology). Bands were detected using enhanced chemiluminescence (Amersham) and film exposure. Membranes were stripped for reproving using a commercial solution (Chemicon).

\section{RNA extraction and RT-PCR}

Total RNA was isolated from cells stimulated for $1 \mathrm{~h}$ with LIF or CNTF, using TRIZOL (Invitrogen). One $\mu \mathrm{g}$ of total RNA was reverse transcribed with random hexamers and $2 \mu \mathrm{l}$ from the reaction were used in PCR containing $2 \mathrm{U}$ Taq DNA polymerase (Invitrogen), $20 \mathrm{pmol}$ of specific primers (Sigma) and $500 \mathrm{mM}$ deoxynucleoside triphosphates. The sequence of the primer used is as follows ( $5^{\prime}$ to $3^{\prime}$ orientation): glyceraldehyde 3-phosphate dehydrogenase

(GAPDH) sense: ATCACCATCTTCCAGGAGCG;

GAPDH antisense: CCTGCTTCACCACCTTCTTG;

Hes 5 sense: ATGGCCCCAAGTACCGTGGCG;

Hes5 antisense: TCACCAGGGCCGCCAGAGGC;

Socs3 sense: ACCAGCGCCACTTCTTCACA;

Socs 3 antisense: GTGGAGCATCATACTGGTCC. The conditions used were: Socs3. denaturalization at $95^{\circ} \mathrm{C}$ for $5 \mathrm{~min}, 30$ cycles at $95^{\circ} \mathrm{C}$ for 40 $\mathrm{s}$, annealing at $58^{\circ} \mathrm{C}$ for $30 \mathrm{~s}$, and elongation at $72^{\circ} \mathrm{C}$ for $40 \mathrm{~s}$. For Hes5. denaturalization at $94^{\circ} \mathrm{C}$ for $5 \mathrm{~min}, 35$ cycles at $94^{\circ} \mathrm{C}$ for $30 \mathrm{~s}$, annealing at $63^{\circ} \mathrm{C}$ for $30 \mathrm{~s}$, and elongation at $72^{\circ} \mathrm{C}$ for $2 \mathrm{~min}$. For $G A P D H$. denaturalization at $95^{\circ} \mathrm{C}$ for $15 \mathrm{~min}, 30$ cycles of denaturalization at $95^{\circ} \mathrm{C}$ for 1 min, annealing at $62^{\circ} \mathrm{C}$ for $1 \mathrm{~min}$, and elongation at $72^{\circ} \mathrm{C}$ for $1 \mathrm{~min}$. In all cases, final extension at $74^{\circ} \mathrm{C}$ for $10 \mathrm{~min}$ was terminated by rapid cooling at $4{ }^{\circ} \mathrm{C}$. PCR products were analyzed in $2 \%$ agarose gel electrophoresis and the size of the reaction products was determined by comparison with molecular weight standards after ethidium bromide staining. As a negative control, reactions with RNA in the absence of retrotranscription were included (-RT in figures).

\section{Immunocytochemistry}

Reported procedures were followed (Velasco et al., 2003; Diaz et al., 2007). In brief, fixed cells were blocked in 10\% normal goat serum (Microlab, México) and permeabilized with $0.3 \%$ Triton X-100 in PBS. Immunocytochemistry was performed with antibodies for GFP (rabbit, Molecular Probes; mouse, Q-BIO gene) to identify transduced cells. Other cell markers were immunodetected with the following antibodies: Nestin (Developmental Studies Hybridoma Bank), $\beta$-Tubulin-III (mouse or rabbit TUJ1, Covance), GFAP (rabbit, DAKO; rat, Zymed), pSTAT3 (Cell Signaling), Sox2 (Chemicon), GP130 (Santa Cruz Biotechnology) and LIFR $\beta$ (Santa Cruz Biotechnology). Primary antibodies were diluted in blocking solution and left at $4^{\circ} \mathrm{C}$ overnight. After that, cells were washed 3 times with PBS, secondary antibodies were applied in a 1:500 dilution, and left $2 \mathrm{~h}$ at room temperature. Goat secondary antibodies coupled to Alexa 350, 488, or 568 (Molecular Probes), or FITC (Southern Biotechnology) were used. Slides were washed again with PBS, and in some cases, nuclei were stained with $1 \mathrm{ng} / \mathrm{ml}$ of Hoechst 33258 (Sigma) in PBS during 10 minutes before being mounted with Aqua Poly/Mount (Polysciences Inc). In all experiments, fixed cells were incubated in the absence of primary antibodies to rule out unspecific staining.

\section{Microscopy and statistical analysis}

Fluorescence was observed with an epifluorescence microscope (Nikon Eclipse) and images were digitalized with a high resolution camera (Nikon DMXF10) and analyzed later. Pictures of each fluorophore were taken as a color channel and mixed using Adobe Photoshop 7.0. In some cases, an Olympus confocal microscope was used. Four to 10 fields per condition were used to quantify the number of cells expressing the 
different cell markers and/or GFP according to each condition using the program Image $1.34 \mathrm{~s}$ (NIH, USA). All data were obtained from at least 3 independent experiments performed in duplicate. The mean of the experiments \pm standard error were plotted using the program Graph Pad Prism 2.01 and the statistical analysis was performed using ANOVA and Student-Newman-Keuls test with $95 \%$ of confidence (WINKS 4.80a; TexaSoft).

\section{Acknowledgements}

We thank Dr. Nicholas Gaiano (Johns Hopkins University) for providing plasmids and advice on retroviral production, Dr. Yvonne Rosenstein and Dr. Gabriel Gutierrez-Ospina for providing antibodies, Israel Lopez from Universidad Autónoma de Ciudad Juárez and Gabriel Orozco from the Microscope Unit for technical help, Dr. Felix Recillas for the use of his luminometer, and all collaborators from the Velasco lab for their continuous support. N. S. R. - R. and E. S. - C. were supported by fellowships from Universidad Nacional Autónoma de México and Conacyt. This work was supported by PAPIIT grants IN226703 and IN224207 from Universidad Nacional Autónoma de México.

\section{References}

ANDROUTSELLIS-THEOTOKIS, A., LEKER, R.R., SOLDNER, F., HOEPPNER, D.J., RAVIN, R., POSER, S.W., RUEGER, M.A., BAE, S.K., KITTAPPA, R. and MCKAY, R.D. (2006) Notch signalling regulates stem cell numbers in vitro and in vivo. Nature 442: 823-826.

ARTAVANIS-TSAKONAS, S., RAND, M.D. and LAKE, R.J. (1999) Notch signaling: cell fate control and signal integration in development. Science 284: 770-776.

BONNI, A., SUN, Y., NADAL-VICENS, M., BHATT, A., FRANK, D.A., ROZOVSKY, I., STAHL, N., YANCOPOULOS, G.D. and GREENBERG, M.E. (1997) Regulation of gliogenesis in the central nervous system by the JAK-STAT signaling pathway. Science 278: 477-483.

CHAMBERS, C.B., PENG, Y., NGUYEN, H., GAIANO, N., FISHELL, G. and NYE, J.S. (2001) Spatiotemporal selectivity of response to Notch1 signals in mammalian forebrain precursors. Development 128: 689-702.

CHANG, M.Y., PARK, C.H., LEE, S.Y. and LEE, S.H. (2004) Properties of cortical precursor cells cultured long term are similar to those of precursors at later developmental stages. Brain Res. Dev. Brain Res. 153: 89-96.

CHOJNACKI, A., SHIMAZAKI, T., GREGG, C., WEINMASTER, G. and WEISS, S. (2003) Glycoprotein 130 signaling regulates Notch1 expression and activation in the self-renewal of mammalian forebrain neural stem cells. J. Neurosci. 23: 1730-1741

CORBIN, J.G., GAIANO, N., JULIANO, S. L., POLUCH, S., STANCIK, E. and HAYDAR, T. F. (2008) Regulation of neural progenitor cell development in the nervous system. J. Neurochem. 106: 2272-2287.

DIAZ, N.F., GUERRA-ARRAIZA, C., DIAZ-MARTINEZ, N.E., SALAZAR, P., MOLINA-HERNANDEZ, A., CAMACHO-ARROYO, I. and VELASCO, I. (2007) Changes in the content of estrogen alpha and progesterone receptors during differentiation of mouse embryonic stem cells to dopamine neurons. Brain Res. Bull. 73: 75-80.

EMERY, B., MERSON, T.D., SNELL, C., YOUNG, K.M., ERNST, M. and KILPATRICK, T.J. (2006) SOCS3 negatively regulates LIF signaling in neural precursor cells. Mol. Cell. Neurosci. 31: 739-747.

GAIANO, N., KOHTZ, J.D., TURNBULL, D.H. and FISHELL, G. (1999) A method for rapid gain-of-function studies in the mouse embryonic nervous system. Nat Neurosci. 2: 812-819.

GAIANO, N., NYE, J.S. and FISHELL, G. (2000) Radial glial identity is promoted by Notch1 signaling in the murine forebrain. Neuron 26: 395-404.

GRANDBARBE, L., BOUISSAC, J., RAND, M., HRABE DE ANGELIS, M., ARTAVANIS-TSAKONAS, S. and MOHIER, E. (2003) Delta-Notch signaling controls the generation of neurons/glia from neural stem cells in a stepwise process. Development 130: 1391-1402.
JOHE, K.K., HAZEL, T.G., MULLER, T., DUGICH-DJORDJEVIC, M.M. and MCKAY, R.D. (1996) Single factors direct the differentiation of stem cells from the fetal and adult central nervous system. Genes Dev. 10: 3129-3140.

KAMAKURA, S., OISHI, K., YOSHIMATSU, T., NAKAFUKU, M., MASUYAMA, N. and GOTOH, Y. (2004) Hes binding to STAT3 mediates crosstalk between Notch and JAK-STAT signalling. Nat. Cell Biol. 6: 547-554.

LUTOLF, S., RADTKE, F., AGUET, M., SUTER, U. and TAYLOR, V. (2002) Notch1 is required for neuronal and glial differentiation in the cerebellum. Development 129: 373-385.

MIZUTANI, K. and SAITO, T. (2005) Progenitors resume generating neurons after temporary inhibition of neurogenesis by Notch activation in the mammalian cerebral cortex. Development 132: 1295-1304.

MOLINA-HERNÁNDEZ, A. and VELASCO, I. (2008) Histamine induces neural stem cell proliferation and neuronal differentiation by activation of distinct histamine receptors. J. Neurochem. 106: 706-717.

MOLNE, M., STUDER, L., TABAR, V., TING, Y.T., EIDEN, M.V. and MCKAY, R.D. (2000) Early cortical precursors do not undergo LIF-mediated astrocytic differentiation. J. Neurosci. Res. 59: 301-311.

MORRISON, S.J., PEREZ, S.E., QIAO, Z., VERDI, J.M., HICKS, C., WEINMASTER, G. and ANDERSON, D.J. (2000) Transient Notch activation initiates an irreversible switch from neurogenesis to gliogenesis by neural crest stem cells. Cel/101: 499-510.

NOCTOR, S.C., FLINT, A.C., WEISSMAN, T.A., DAMMERMAN R.S. and KRIEGSTEIN, A.R. (2001) Neurons derived from radial glia cells establish units in neocortex. Nature 409: 714-720.

NYE, J.S., KOPAN, R. and AXEL, R. (1994) An activated Notch suppresses neurogenesis and myogenesis but not gliogenesis in mammalian cells. Deve/ opment 120: 2421-2430.

OISHI, K., KAMAKURA, S., ISAZAWA, Y., YOSHIMATSU, T., KUIDA, K., NAKAFUKU, M., MASUYAMA, N. and GOTOH, Y. (2004) Notch promotes survival of neural precursor cells via mechanisms distinct from those regulating neurogenesis. Dev. Biol. 276: 172-184.

PITMAN, M., EMERY, B., BINDER, M., WANG, S., BUTZKUEVEN, H. and KILPATRICK, T.J. (2004) LIF receptor signaling modulates neural stem cell renewal. Mol. Cell. Neurosci. 27: 255-266.

QIAN, X., SHEN, Q., GODERIE, S.K., HE, W., CAPELA, A., DAVIS, A.A. and TEMPLE, S. (2000) Timing of CNS cell generation: a programmed sequence of neuron and glial cell production from isolated murine cortical stem cells. Neuron 28: $69-80$.

RAJAN, P. and MCKAY, R.D. (1998) Multiple routes to astrocytic differentiation in the CNS. J. Neurosci. 18: 3620-3629.

SAUVAGEOT, C.M. and STILES, C.D. (2002) Molecular mechanisms controlling cortical gliogenesis. Curr. Opin. Neurobiol. 12: 244-249.

TANIGAKI, K., NOGAKI, F., TAKAHASHI, J., TASHIRO, K., KUROOKA, H. and HONJO, T. (2001) Notch1 and Notch3 instructively restrict bFGF-responsive multipotent neural progenitor cells to an astroglial fate. Neuron 29: 45-55.

TOKUNAGA, A., KOHYAMA, J., YOSHIDA, T., NAKAO, K., SAWAMOTO, K. and OKANO, H. (2004) Mapping spatio-temporal activation of Notch signaling during neurogenesis and gliogenesis in the developing mouse brain. $J$. Neurochem. 90: 142-154.

VELASCO, I., VELASCO-VELAZQUEZ, M.A., SALAZAR, P., LAJUD, N. and TAPIA, R. (2003) Influence of serum-free medium on the expression of glutamate transporters and the susceptibility to glutamate toxicity in cultured cortical neurons. J. Neurosci. Res. 71: 811-818.

WANG, S., SDRULLA, A.D., DISIBIO, G., BUSH, G., NOFZIGER, D., HICKS, C. WEINMASTER, G. and BARRES, B.A. (1998) Notch receptor activation inhibits oligodendrocyte differentiation. Neuron 21: 63-75.

YOON, K. and GAIANO, N. (2005) Notch signaling in the mammalian central nervous system: insights from mouse mutants. Nat. Neurosci. 8: 709-715.

YOON, K., NERY, S., RUTLIN, M.L., RADTKE, F., FISHELL, G. and GAIANO, N. (2004) Fibroblast growth factor receptor signaling promotes radial glial identity and interacts with Notch1 signaling in telencephalic progenitors. J. Neurosci. 24: 9497-9506. 


\section{Further Related Reading, published previously in the Int. J. Dev. Biol.}

See our recent Special Issue Stem Cells and Transgenesis, edited by Robert E. Hammer and Richard R. Behringer at: http://www.ijdb.ehu.es/web/contents.php?vol=42\&issue=7

Notch-Off: a perspective on the termination of Notch signalling

Rita Fior and Domingos Henrique

Int. J. Dev. Biol. (2009) doi: 10.1387/ijdb.072309rf

Neural stem cells at the crossroads: MMPs may tell the way

Gaetana A. Tonti, Ferdinando Mannello, Emanuele Cacci and Stefano Biagioni Int. J. Dev. Biol. (2009) 53: 1-17

Neural differentiation from human embryonic stem cells in a defined adherent culture condition

Hossein Baharvand, Narges-Zare Mehrjardi, Maryam Hatami, Sahar Kiani, Mahendra Rao and Mahdi-Montazer Haghighi

Int. J. Dev. Biol. (2007) 51: 371-378

Notch in vertebrates - molecular aspects of the signal

Ken-Ichi Katsube and Kei Sakamoto

Int. J. Dev. Biol. (2005) 49: 369-374

Distinct neural precursors in the developing human spinal cord

Sally Walder and Patrizia Ferretti

Int. J. Dev. Biol. (2004) 48: 671-674

Notch activity is required to maintain floorplate identity and to control neurogenesis in the chick hindbrain and spinal cord

Isabelle le Roux, Julian Lewis and David Ish-Horowicz

Int. J. Dev. Biol. (2003) 47: 263-272

5 yr ISI Impact Factor $(2008)=3.271$

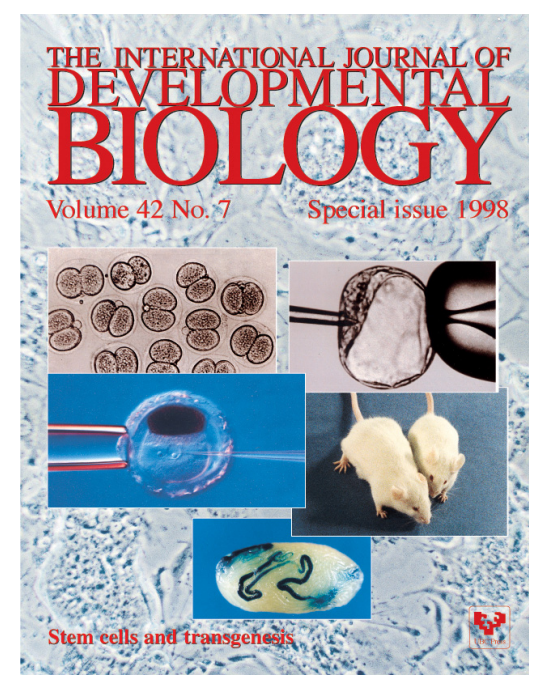

